\title{
E-Commerce Apps - Solutions for Farm-Household in the Context of the Covid-19 Pandemic: Research on Suppliers of Lychee Products According to Global Gap Standards
}

\author{
Thi Hoai Huong Hoang ${ }^{1}$, Thi Yen Le ${ }^{2}$ \\ ${ }^{1}$ Quy Nhon University, Viet Nam \\ ${ }^{2}$ Hanoi Architectural University, Viet Nam
}

\begin{abstract}
In the context of the outbreak of the Covid-19 pandemic in countries around the world, it is extremely hard for farmers to consume agricultural products, thereby affecting their production results. This study was designed to analyze the factors affecting the production and business results of lychee farmers in Vietnam in the context of the influence of the Covid 19 pandemic. Data for the study was collected from a survey of about 400 lychee production households according to Global Gap standards in Vietnam. Research findings have shown that the revenue from the supply of lychee products of farmers in Vietnam has decreased after the effects of Covid 19. Along with that, factors also have different degrees of influence on the business results of lycheeproducing households. Especially in the context of the Covid 19 pandemic, e-commerce has become an effective consumption channel, supporting the consumption of products of lychee producers in Vietnam. In the light of those findings, the author provided recommendations for lychee product suppliers in Vietnam on how to solve their problems.
\end{abstract}

KEYWORDS: Apps, E-Commerce, Lychee, Product Consumption, Vietnam, Value Chain

\section{INTRODUCTION}

The worldwide Covid-19 pandemic has had a significant effect on all countries' production and business operations, including Vietnam. As a purely agricultural country with over $70 \%$ working in the farming sector, the continuous application of social distancing measures as adjusting the production schedule has affected the production and consumption of products in general and agricultural production in particular.

Agricultural products that have been granted Global Gap standard certificates in Vietnam have the opportunity to export to countries around the world, including lychee products; however, the outbreak of the Covid-19 pandemic in Vietnam since early 2020 has negatively affected product consumption, particularly exports to countries around the world. Producers expect exports to take place because it can bring higher economic value, however, the restrictions on flights as well as the difficulties caused by countries with limitations due to the influence of the Covid 19 pandemic, to control the Covid 19 pandemic, manufacturers, as well as traders and distribution enterprises, have been forced to change their marketing strategies for agricultural products.

One of the changes shown is that farmers - who produce agricultural products using e-commerce platforms, e-commerce sites to carry out the consumption of their products within the country or in other words that is to encourage domestic consumption, which has partly solved the problem of consuming agricultural products for producers in areas that are blocked due to the influence of Covid 19.

In Vietnam, according to the GSO (2021) and World Bank (2020), as of April 2020, the effects of Covid 19 have affected about $85.7 \%$ of firms out of a total of 126,565 surveyed enterprises. Out of the total number of affected companies, the industry construction and service sectors are most affected by the Covid-19 epidemic with the proportion of businesses affected are $86.1 \%$ and $85.9 \%$, respectively; while the agriculture, forestry, and fishery sectors are less affected with $78.7 \%$. Some economic sectors have a high rate of enterprises being negatively affected by the Covid-19 epidemic, such as: aviation 100\%, accommodation services 97.1\%, food services $95.5 \%$, activities of travel agencies $95.7 \%$, education and training $93.9 \%$, textile and garment industries, leather production, leather products, production of electronic products, car manufacturing all have a rate of over $90 \%$.

The difficulties brought by the Covid-19 pandemic have caused fluctuations in the consumption of agricultural products of households producing farm products (hereinafter referred to as farmers) in Vietnam, which in this study are the farmers producing 


\section{International Journal of Current Science Research and Review}

ISSN: 2581-8341

Volume 04 Issue 12 December 2021

DOI: 10.47191/ijcsrr/V4-i12-03, Impact Factor: 5.825

IJCSRR@ 2021

Www.ijesrr.org

lychee products. This study was designed to analyze the impact of the COVID-19 pandemic on the production and business results of litchi farmers in Vietnam. Specifically, the study examines the influence of factors on business results of farmers, consider comparing before and after the Covid 19 pandemic has affected the income of farmers through variables such as product selling price, number of employees, along with that are demographic factors and natural conditions of the lychee production area in Vietnam.

\section{RESEARCH OVERVIEW}

Countless countries around the world have been affected by the Covid-19 pandemic, which has not only affected the health of the population but has had a serious impact on the economy and social security of the countries. For economies, the Covid 19 pandemic has caused difficulties for all actors involved in the economy, from large corporations to enterprises, and affects workers directly involved in the production and business processes of enterprises (Alessa et al, 2021; Nguyen \& Tran, 2021). Enterprises are a crucial link in the operation of the economy, the influence of the Covid-19 pandemic has created unwanted changes in firms, production stagnation, high inventory level, poor business performance, many of the companies had to declare bankruptcy or close their production and stores for a long time (Shen et al, 2020; Obrenovic et al, 2020; Pattiruhu \& Paais, 2020). The effects of Covid 19 have been studied by researchers with different approaches, but there is a common point in these studies when they all suggest that the Covid 19 pandemic has had negative impacts on people's incomes as well as directly affecting people's social behaviors (Benzerra, Silva, Soares et al, 2020; Qian \& Fan, 2020).

Regarding the supply of agricultural products in developing countries, farmers are the key actors in providing these products. Their income from products is the source of revenue they get from supplying products and performing income-generating activities. Farmer's income is influenced by different factors, according to DFID (1999), Farmer's income is nfluenced by five resources: Human resources, financial resources, physical resources, social resources, and natural resources. However, when the outbreak of the Covid-19 pandemic caused damage to the income of farmers, it forced farmers to make changes to adapt to the fluctuations caused by the Covid-19 pandemic.

The factors influencing the production and business results of farm households have been studied in different studies, however, when studying the outputs of farmers, they all agree to use income indicators to measure and the input elements affecting income are considered, including factors relating to capital, labor and science and technology Abdulai and CroleRees (2001); Yang (2004); Tran (2013); Tran and Vu (2014); Siegel (2005); Le et al (2020). The factors are described through different scales; these factors have different degrees of influence on the income of farmers.

\section{RESEARCH METHODOLOGY}

\subsection{Data collection methods}

Lychee production in Vietnam is specific to small-scale farming, which is directly produced and supplied by farmers and collected through enterprises or middleman to distribute to the market. Therefore, the study carried out a direct survey of lychee farmers in Vietnam to serve as data for the study.

The research team surveyed 500 households producing lychee according to Global Gap standards in Vietnam, after completing the survey, the group collected the survey forms; out of a total of 500 distributed questionnaires, 436 questionnaires returned, and 136 survey questionnaires did not meet the requirements for complete data entry survey, the group has removed that survey vote, leaving 400 survey votes that meet the requirements, the group has performed data analysis on those 400 survey votes. With an observation scale of 400 observations, corresponding to 400 survey samples, it meets the minimum sample size required to perform statistical operations according to Nguyen's point of view (2014).

About the survey time: Time to survey from May to June 2021.

Survey content: The survey of the research team was carried out according to the survey form designed according to the survey form of GSO (2020) and divides information into three parts: Part 1 information about the surveyed subjects; Part 2 provides information on the impact of the Covid-19 pandemic on the production and business results of lychee growers, and Part 3 is information on comparing the effects before and after the Covid 19 pandemic.

Survey method: Carry out surveys directly with the respondents. 


\section{International Journal of Current Science Research and Review}

ISSN: 2581-8341

Volume 04 Issue 12 December 2021

DOI: 10.47191/ijesrr/V4-i12-03, Impact Factor: 5.825

\subsection{Data Analysis Methods}

To analyze the impact of Covid 19 on the production and business results of households producing lychee products, the study uses the following scales:

\begin{tabular}{|c|c|c|c|c|}
\hline Items & Symbols & Explain & Selection basis & $\begin{array}{l}\text { Dimensional } \\
\text { expectation of } \\
\text { impact }\end{array}$ \\
\hline \multicolumn{5}{|l|}{ Dependent variables } \\
\hline $\begin{array}{l}\text { Income of } \\
\text { production } \\
\text { household }\end{array}$ & $\mathrm{Y}$ & $\begin{array}{l}\text { The direct income of } \\
\text { lychee-producing } \\
\text { households earned } \\
\text { annually. Unit is million } \\
\text { VND/year }\end{array}$ & $\begin{array}{l}\text { Nguyen and Bui (2011); } \\
\text { Abdulai and CroleRees } \\
\text { (2001); Yang (2004); Tran } \\
\text { (2013); Tran and Vu (2014); } \\
\text { Siegel (2005); Le et al } \\
\text { (2020); Nguyen et al (2021) }\end{array}$ & \\
\hline \multicolumn{5}{|c|}{ Independent variables } \\
\hline $\begin{array}{l}\text { Number } \\
\text { employees } \\
\text { participate in the } \\
\text { production }\end{array}$ & $\mathrm{X} 1$ & $\begin{array}{l}\text { The number of workers } \\
\text { directly involved in lychee } \\
\text { production in the } \\
\text { households surveyed. } \\
\text { Calculated per worker unit }\end{array}$ & $\begin{array}{l}\text { Abdulai and CroleRees, } \\
\text { 2001; Yang, } 2004\end{array}$ & + \\
\hline $\begin{array}{l}\text { Location of the } \\
\text { lychee production } \\
\text { area }\end{array}$ & $\mathrm{X} 2$ & $\begin{array}{l}\text { This is a scale used to } \\
\text { measure the convenience of } \\
\text { the supply area for product } \\
\text { consumption, especially in } \\
\text { the context of Covid } 19 \text {, the } \\
\text { transportation is more } \\
\text { challenging than before } \\
\text { Covid } 19 \text { took place }\end{array}$ & $\begin{array}{l}\text { Klasen, Priebe and Rudolf, } \\
2013 ; \quad \text { Setini, Yasa, } \\
\text { Supartha et al (2021) }\end{array}$ & + \\
\hline $\begin{array}{l}\text { Number of areas } \\
\text { consuming lychee }\end{array}$ & $\mathrm{X} 3$ & $\begin{array}{l}\text { This factor measures the } \\
\text { diversity of product } \\
\text { consumption markets. }\end{array}$ & $\begin{array}{l}\text { Oré-Calixto and Vicente- } \\
\text { Ramos (2021); Setini, } \\
\text { Yasa, Supartha et al (2021); } \\
\text { Dewi, Hajadi, Handranata } \\
\text { et al (2021) }\end{array}$ & + \\
\hline $\begin{array}{l}\text { Using e-commerce } \\
\text { tools for product } \\
\text { consumption }\end{array}$ & $\mathrm{X} 4$ & $\begin{array}{l}\text { In the context of Covid } 19 \text {, } \\
\text { e-commerce tools have } \\
\text { been utilized to deliver and } \\
\text { introduce products to the } \\
\text { market. }\end{array}$ & $\begin{array}{l}\text { Oré-Calixto and Vicente- } \\
\text { Ramos (2021); Setini, } \\
\text { Yasa, Supartha et al (2021); } \\
\text { Dewi, Hajadi, Handranata } \\
\text { et al (2021) }\end{array}$ & + \\
\hline $\begin{array}{l}\text { Product selling } \\
\text { price }\end{array}$ & $\mathrm{X} 5$ & $\begin{array}{l}\text { Measure the selling price of } \\
\text { the product. } \\
\text { Unit: thousand VND/10 kg }\end{array}$ & $\begin{array}{l}\text { Mukhsin and Suryanto } \\
\text { (2021); Anita and Pratomo } \\
\text { (2021) }\end{array}$ & + \\
\hline Covid 19 & X6 & $\begin{array}{l}\text { This is a dummy variable to } \\
\text { measure the influence of } \\
\text { the Covid-19 pandemic on } \\
\text { the business results of } \\
\text { farming households }\end{array}$ & $\begin{array}{l}\text { Benzerra, Silva, Soares et } \\
\text { al (2020); Qian and Fan, } \\
\text { 2020; Anita and Pratomo } \\
(2021) \text {. Setini, Yasa, } \\
\text { Supartha et al (2021). }\end{array}$ & $-/+$ \\
\hline
\end{tabular}




\section{International Journal of Current Science Research and Review}

ISSN: 2581-8341

Volume 04 Issue 12 December 2021

DOI: 10.47191/ijesrr/V4-i12-03, Impact Factor: 5.825

IJCSRR@ 2021

WWw.ijesrr.org

Besides, in this study, the authors have studied the factors belonging to other resources affecting the income of farmers such as financial resources, physical resources, natural resources, social and human resources from the perspective of DFID (1999), however, the authors will not analyze these factors in-depth but only focus on the elements that show the impact of Covid-19 on the production results of lychee farmers in Vietnam.

\section{FINDINGS}

The production chain of lychee products in Vietnam of lychee farmers is as follows:

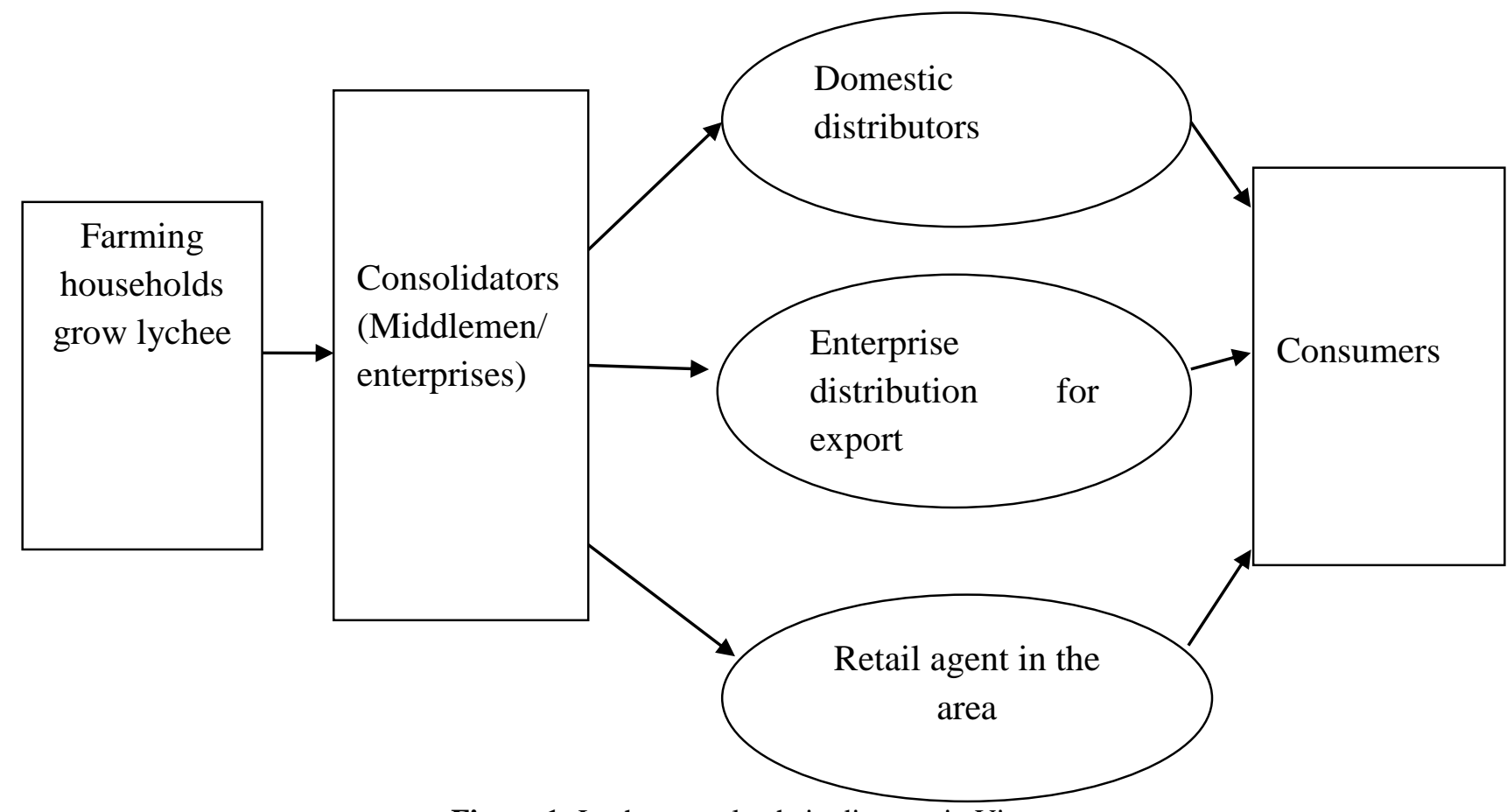

Figure 1: Lychee supply chain diagram in Vietnam

The supply of products to the market is distributed into the following channels:

Producers are farmers who grow lychee in Vietnam, after harvesting, they sell to distributors 1 called consolidator, these consolidators can be enterprises or they can be both domestic and international middlemen coming to the area to purchase.

From the middleman's channel, it will be distributed to the market through three consumption channels:

Firstly, middlemen and enterprises will supply to distributors who are supermarkets or firms and product suppliers for the domestic market. From there, it will be delivered to consumers.

Secondly, the distributor will purchase and distribute products to enterprises specializing in exporting products when the products meet the standards for export so that they will be delivered to consumers.

Third, distributors will supply to retailers in the local market where they supply; usually, these markets are small and account for a very low proportion of the value chain of lychee supply in Vietnam.

Due to the impact of the Covid 19 pandemic, in 2021, the consumption of lychee products in the Vietnamese market has applied an e-commerce system to meet the requirements of bringing products to consumers by direct order method and will have a logistics unit to support delivery to consumers. For a developing country like Vietnam, this method for domestic suppliers and distributors as well as consumers is still relatively new.

With the production and business results of the farmers who directly supply lychee products to the market, with the difficulties caused by the Covid pandemic, the business results of farmers are also greatly affected; their revenue results when compared between 2019 and 2021 are as follows: 


\section{International Journal of Current Science Research and Review}

ISSN: 2581-8341

Volume 04 Issue 12 December 2021

DOI: 10.47191/ijesrr/V4-i12-03, Impact Factor: 5.825

IJCSRR@ 2021

www.ijesrr.org

Table 1: Revenue of lychee suppliers

Unit: Million VND/ year

\begin{tabular}{|l|l|l|l|}
\hline \multirow{2}{*}{ Years } & Before Covid 19 & After Covid 19 \\
\cline { 2 - 4 } & $\mathbf{2 0 1 9}$ & $\mathbf{2 0 2 0}$ & $\mathbf{2 0 2 1}$ \\
\hline Revenue from lychee on average / year & 236.12 & 205.38 & 201.06 \\
\hline Compare & $/$ & -30.74 & -4.32 \\
\hline
\end{tabular}

Source: Author's survey results

The revenue of lychee suppliers has a dramatic change in the period of 2019-2021, taking 2020 as the year when Covid 19 occurred, when comparing before and after Covid 19 took place, the revenue of lychee growers from lychee products has decreased, the cause of the decrease in sales according to the research results is the decrease in consumption. It is difficult for lychee products to find markets for consumption and transport agricultural products, especially fresh lychee; if not handled carefully, it will cause damage and not meet the consumption conditions. During the Covid 19 pandemic, localities implemented "social distancing", which led to a difficult circulation of goods, so the consumption of products is also much more difficult. From that, it has affected the revenue from lychee of farmers.

With the survey results of litchi growers in Vietnam, the research team carried out a regression to estimate the influence of these factors on the income of households growing this product. Specific results are as follows:

First, the study tests the fit of the regression function form and some model defects.

Table 2a: Results of testing the fit and some defects of the model

\begin{tabular}{|c|c|c|c|c|c|c|c|c|c|c|}
\hline \multicolumn{11}{|c|}{ Model Summary } \\
\hline \multirow[b]{2}{*}{ Model } & \multirow[b]{2}{*}{$\mathrm{R}$} & \multirow[b]{2}{*}{$\begin{array}{l}\mathrm{R} \\
\text { Square }\end{array}$} & \multirow[b]{2}{*}{$\begin{array}{l}\text { Adjusted } \\
\text { R Square }\end{array}$} & \multirow{2}{*}{$\begin{array}{l}\text { Std. } \\
\text { Error of } \\
\text { the } \\
\text { Estimate }\end{array}$} & \multicolumn{5}{|c|}{ Change Statistics } & \multirow[b]{2}{*}{$\begin{array}{l}\text { Durbin- } \\
\text { Watson }\end{array}$} \\
\hline & & & & & $\begin{array}{l}\mathrm{R} \\
\text { Square } \\
\text { Change }\end{array}$ & $\begin{array}{l}\text { F } \\
\text { Change }\end{array}$ & df1 & $\mathrm{df} 2$ & $\begin{array}{l}\text { Sig. F } \\
\text { Change }\end{array}$ & \\
\hline 1 &, $954^{\mathrm{a}}$ & .910 & .908 & 28.629 & .910 & 438.676 & 9 & 390 & .000 & 2.254 \\
\hline
\end{tabular}

The source: Processing results from the survey data with the help of SPSS20.0 software

Durbin-Watson coefficient $=2.254$, the research model has no correlation

With the coefficient R Square $=0.910$, the independent variables in the model explain about $91 \%$ of the dependent variable

The test results show that the model chosen by the author is suitable when there is no defect in autocorrelation in the model, and the independent variables explain about $91 \%$ of the dependent variable.

Table 2b: Results of testing the fit and some defects of the model

\begin{tabular}{|l|l|l|l|l|l|l|}
\hline \multicolumn{2}{|l|}{ ANOVA } & Sum of Squares & Df & Mean Square & F & Sig. \\
\hline \multirow{3}{*}{1} & Regression & 3235869.912 & 9 & 359541.101 & 438.676 &, 000 \\
\cline { 2 - 8 } & Residual & 319646.088 & 390 & 819.605 & & \\
\cline { 2 - 8 } & Total & 3555516.000 & 399 & & & \\
\hline
\end{tabular}

The source: Processing results from the survey data with the help of SPSS20.0 software

The results from Table $2 \mathrm{~b}$ show:

With coefficient $\mathrm{Sig}=0.000 ; \mathrm{F}$ test $=438,676$, so the research model is suitable

Utilizing the data collected from the household survey in conjunction with SPSS 20.0 software. The author uses the leastsquares method to analyze the influence of factors on the income of lychee-producing households in Vietnam. 


\section{International Journal of Current Science Research and Review}

ISSN: 2581-8341

Volume 04 Issue 12 December 2021

DOI: 10.47191/ijesrr/V4-i12-03, Impact Factor: 5.825

IJCSRR@ 2021

www.ijesrr.org

Table 3: Results of regression models

\begin{tabular}{|c|c|c|c|c|c|c|}
\hline \multicolumn{7}{|c|}{ Coefficients $^{\mathrm{a}}$} \\
\hline \multirow{2}{*}{\multicolumn{2}{|c|}{ Model }} & \multicolumn{2}{|c|}{ Unstandardized Coefficients } & $\begin{array}{l}\text { Standardized } \\
\text { Coefficients }\end{array}$ & \multirow[t]{2}{*}{$\mathrm{T}$} & \multirow[t]{2}{*}{ Sig. } \\
\hline & & $\mathrm{B}$ & Std. Error & Beta & & \\
\hline \multirow{10}{*}{1} & (Constant) & 39.132 & 10.800 & & 3.623 & .000 \\
\hline & $\mathrm{X} 2$ & 1.013 & .617 & .033 & 1.642 & .101 \\
\hline & $\mathrm{X} 1$ & 23.729 & 3.359 & .480 & 7.064 & .000 \\
\hline & X3 & 16.144 & 2.680 & .150 & 6.024 & .000 \\
\hline & $\mathrm{X} 4$ & 32.123 & 5.588 & .400 & 5.749 & .000 \\
\hline & X5 & .128 & .027 & .126 & 4.831 & .000 \\
\hline & X6 & -7.487 & 2.136 & -.088 & -3.504 & .001 \\
\hline & $\mathrm{X7}$ & -12.282 & 2.186 & -.140 & -5.618 & .000 \\
\hline & $\mathrm{X} 8$ & 3.200 & 2.499 & .035 & 1.280 & .201 \\
\hline & X9 & 16.359 & 6.100 & .087 & 2.682 & .008 \\
\hline
\end{tabular}

The source: Processing results from the survey data with the help of SPSS20.0 software

Based on the results in Table 3 show that all the variables in the study are statistically significant with an error of 0.1 , several different factors affect the income of lychee-producing households; however, the degree of influence of the factors is different. Moreover, in this study, the author focuses on analyzing the effects of three factors X4 (using e-commerce tools in product consumption); X5 (the price of the product), and X6 are the effects of Covid-19 according to the assessment of the producer household to see the difference between before and after Covid 19 affects the production households.

For the variable using e-commerce tools for consumption of output products, there is a positive relationship with household income, this represents a dramatic difference for producers and dealers who buy wholesale products in Vietnam. In Vietnam, for agricultural products in general and lychee products in particular, before Covid 19 occurred, all trade exchanges took place through traditional channels, traditional partners of the producer household, the phenomenon of price pressure when purchasing is also quite common. When Covid 19 took place, consumption became more and more difficult due to import restrictions of international markets as well as difficulties in goods movement in the domestic market. A measure was successfully implemented, especially during the Covid pandemic of 2021 in areas that supplied lychee products, concerns about the consumption of products for farmers, the price of consumer products requires state management agencies and domestic consumers as well as enterprises to accompany distribution channels as well as farmers. In particular, putting the goods on the e-commerce platform has made it easier for the goods to reach consumers. Therefore, it has partly solved the problem of product consumption for the people.

The selling price factor of the product, the selling price of the actual product shows, when products are exported to foreign countries and protected by state agencies, along with putting products on e-commerce floors has somewhat stabilized product prices for people, stable product prices have ensured direct income and revenue from lychee for actors involved in the supply chain of that lychee product.

The Covid 19 factor represents the time and effect of the pandemic on the income of producing households based on the time and effects of the pandemic. When covid 19 took place, the earnings of production households decreased, some products were sold to the market, however, there were still many products that had to be abandoned and could not be handled when the Covid 19 pandemic broke out. The influence of the volume of consumable products has reduced the income and direct revenue from lychee of actors participating in the value chain as well as of lychee producers themselves. Additionally, the difficulties caused by transportation, logistics costs, and related costs all increase, in general, it affects the income of producing households in a significant way. 


\section{International Journal of Current Science Research and Review}

ISSN: 2581-8341

Volume 04 Issue 12 December 2021

DOI: 10.47191/ijcsrr/V4-i12-03, Impact Factor: 5.825

IJCSRR@ 2021

Www.ijesrr.org

Besides examining these factors in detail, the study also pointed out the effects of other factors on the income of lycheeproducing households in Vietnam.

\section{SOME RECOMMENDATIONS}

To partially solve the difficulties for Vietnamese lychee producers, especially in the face of the current Covid 19 outbreak, some recommendations are proposed by the research team as follows:

Firstly, it is necessary to build and create domestic and international e-commerce sites to supply agricultural products in general and lychee products in particular to consumers. Since then, products are promoted to different consumer markets, contributing to reducing pressure and difficulties for producers, especially in a country where agricultural producers are mostly smallholder farmers.

Secondly, equipped with knowledge of information technology as well as the regulations of different markets for product suppliers. Having information technology knowledge will help manufacturers to access and supply their products through ecommerce platforms. Knowing market requirements will help ensure products are supplied to meet the standards of the markets.

Thirdly, the government, as well as state management agencies, need to have policies to support lychee product producers, especially policies to promote the product, seek to expand the market for special goods for farmers.

Fourth, enterprises and merchants need to accompany farmers to overcome difficulties in consuming special products in the context of the outbreak of the Covid-19 pandemic.

Fifth, actors involved in the value chain of lychee products need to coordinate to organize product introduction fairs at local and international locations to promote the quality and image of the product to international and domestic friends. In addition, building videos, leaflets, and other forms of product promotion are also effective forms to promote products.

Sixth, the state and localities need to prioritize investment in building infrastructure for production and product consumption networks.

\section{REFERENCES}

1. Anita, T., \& Pratomo, A. (2021). Food safety management and food quality in hospitality industry during covid-19 pandemic. Uncertain Supply Chain Management, 9(3), 681-686

2. Abdulai, A., \& CroleRees, A. (2001). Determinants of income diversification amongst rural households in Southern Mali. Food policy, 26(4), 437-452

3. Alessa, A. A., Alotaibie, T. M., Elmoez, Z., \& Alhamad, H. E. (2021). Impact of COVID-19 on Entrepreneurship and Consumer Behaviour: A Case Study in Saudi Arabia. The Journal of Asian Finance, Economics and Business, 8(5), 201210. https://doi.org/10.13106/jafeb.2021.vol8.no5.0201

4. Bezerra, A. C. V., Silva, C. E. M. D., Soares, F. R. G., \& Silva, J. A. M. D. (2020). Factors associated with people's behavior in social isolation during the Covid-19 pandemic. Ciencia \& saude coletiva, 25, 2411-2421, https://www.scielosp.org/article/csc/2020.v25suppl1/2411-2421/en/\#

5. Benayas. J. M.R., Ana, M., Jose M.N., \& Jennifer J.S. (2007). Abandonment of agricultural land: An overview of drivers and consequences. CAB reviews: Perspectives in agriculture, veterinary science, nutrition and natural resources. 2(57), 1-14, doi: 10.1079/PAVSNNR20072057

6. DFID. (1999). Sustainable livelihood guidance sheets, Hall- International, Inc

7. Dewi, D., Hajadi, F., Handranata, Y., \& Herlina, M. (2021). The effect of service quality and customer satisfaction toward customer loyalty in service industry. Uncertain Supply Chain Management, 9(3), 631-636

8. GSO, (2021), Report the influence on laborers' income and employment, www.gso.gov.vn

9. Huynh, T.D.X \& Mai, V.N. (2011). Phan tich cac yeu to anh huong den thu nhap cua ho chan nuoi gia cam o dong bang song cuu long (Analysis of factors affecting the income of poultry farmers in the Mekong Delta), Scientific journals. 17 (b), 87-96.

10. Klasen, S., Priebe, J., \& Rudolf, R. (2013). Cash crop choice and income dynamics in rural areas: evidence for post-crisis Indonesia. Agricultural Economics, 44(3), 349-364 


\section{International Journal of Current Science Research and Review}

ISSN: 2581-8341

Volume 04 Issue 12 December 2021

DOI: 10.47191/ijcsrr/V4-i12-03, Impact Factor: 5.825

IJCSRR@ 2021

WWw.ijesrr.org

11. Le, T., Pham, V., Cu, T., Pham, M., and Dao, Q. (2020). The effect of industrial park development on people's lives. Management Science Letters. 10(7), 1487-1496, doi: 10.5267/j.msl.2019.12.018

12. Le, L.H., \& Le, T.N. (2020). Determinants of Income Diversification among Rural Households in the Mekong River Delta: The Economic Transition Period. Journal of Asian finance, Economics and business. 7(5), 291-304, doi:10.13106/jafeb.2020.vol7.no5.291

13. Mukhsin, M., \& Suryanto, T. (2021). The effect of supply agility mediation through the relationship between trust and commitment on supply chain performance. Uncertain Supply Chain Management, 9(3), 555-562

14. Nguyen, T., Tran, Q., Ho, D., \& Duong, D. (2021). The effect of supply chain linkages on the business performance: Evidence from Vietnam. Uncertain Supply Chain Management, 9(3), 529-538

15. Nguyen, H. N., \& Tran, M. D. (2021). The Effect of Perceived Organizational Support on Employee Engagement During the COVID-19 Pandemic: An Empirical Study in Vietnam. The Journal of Asian Finance, Economics and Business, 8(6), 415-426, https://doi.org/10.13106/jafeb.2021.vol8.no6.0415

16. Nguyen, V.T. (2014). Giao trinh thuc hanh nghien cu trong kinh te va quan tri kinh doanh (Curriculum of research practice in economics and business administration), National Economics University publishing house.

17. Nguyen.Q.N \& Bui.V.T. (2011). Factors affecting the income of ethnic minorities in the Mekong Delta. Science journal. $18 \mathrm{a}, 240-250$

18. Tran, Q.T. (2013). Livelihood strategies for coping land loss among households in VietNam's sub-urban areas. Asian social science. 9(15), 33-46, doi:10.5539/ass.v9n15p33

19. Tran, Q.T., \& Vu, V. H. (2014). The impact of land loss on household income: The case of HaNoi's sub-urban areas, Viet Nam, International Journal of Business and Society. 15(2), 339 - 358.

20. Siegel. (2005) Using an asset-based approach to identify drivers of sustainable rural growth and poverty reduction in Central America: A conceptual framework. World Bank Policy Research Working Paper 3475.

21. Setini, M., Yasa, N., Supartha, I., \& Giantari, I. (2021). Toward marketing performance through supply chain management and knowledge sharing during the Covid19. Uncertain Supply Chain Management, 9(3), 609-616

22. Shen, H., Fu, M., Pan, H., Yu, Z., \& Chen, Y. (2020). The impact of the Covid-19 pandemic on firm performance. Emerging Markets Finance and Trade. 56(10), 2213-2230

23. Obrenovic, B., Du, J., Godinic, D., Tsoy, D., Khan, M. A. S., \& Jakhongirov, I. (2020). Sustaining enterprise operations and productivity during the Covid-19 pandemic: "Enterprise Effectiveness and Sustainability Model". Sustainability. $12(15), 5981$.

24. Oré-Calixto, S., \& Vicente-Ramos, W. (2021). The effect of digital marketing on customer relationship management in the education sector: Peruvian case. Uncertain Supply Chain Management, 9(3), 549-554

25. Pattiruhu, j. R., \& Paais, m. (2020). Effect of Liquidity, Profitability, Leverage, and Firm Size on Dividend Policy. The Journal of Asian Finance, Economics, and Business. 7(10), 35-42.

https://doi.org/10.13106/JAFEB.2020.VOL7.NO10.035

26. Qian, Y., \& Fan, W. (2020). Who loses income during the Covid-19 outbreak? Evidence from China. Research in Social Stratification and Mobility, 68, 100522,

https://www.sciencedirect.com/science/article/pii/S0276562420300585?via\%3Dihub\#bib0055

27. World Bank. (2020). Impact of Covid-19 on firms in Vietnam. The quick survey report on enterprises and Covid-19, Report No.1.

Cite this Article: Thi Hoai Huong Hoang, Thi Yen Le (2021). E-Commerce Apps - Solutions for Farm-Household in the Context of the Covid-19 Pandemic: Research on Suppliers of Lychee Products According to Global Gap Standards. International Journal of Current Science Research and Review, 4(12), 1632-1639 